\title{
Language Choice in Female Dormitory of the Boarding School of Islam Al-Mukmin Ngruki
}

\author{
Eka Susylowati \\ Universitas Sebelas Maret \\ Surakarta Indonesia \\ esusylowati@gmail.com \\ Wakit Abdullah \\ Postgraduate Program, \\ Universitas Sebelas Maret \\ Surakarta Indonesia \\ abdullahwakit@yahoo.com
}

Descriptive Linguistics Study Program, Postgraduate Program

\author{
Sumarlam \\ Postgraduate Program, \\ Universitas Sebelas Maret \\ Surakarta Indonesia \\ sumarlam@staff.uns.ac.id \\ Sri Marmanto \\ Postgraduate Program, \\ Universitas Sebelas Maret \\ Surakarta Indonesia
}

\begin{abstract}
Al-Mukmin Ngruki Islamic Boarding School is multilingual community. The aim of this study is to find out the language choice that used by students in the female dormitory Al-Mukmin Ngruki Islamic Boarding School. This study is belongs to Sosiolinguistics that belongs to with qualitative research approach. Data The were collection collected of data through observation, recording, and interview. The result of the study shows that there are some kinds of some languages used by the female students in the female dormitory in Al-Mukmin Ngruki Boarding School. They are non standart standard Indonesia languages, Javanese Ngoko, English, Arabic, and the other local languages. The most students use non standart Indonesia in their daily life communication.
\end{abstract}

Keywords: language choice, female students' boarding school, language variation

\section{INTRODUCTION}

Pesantren Al-Mukmin Ngruki in existence experienced up and down due to several things, the pesantren is famous to abroad because of the popular in teaching science but not infrequently that the pesantren and its environment is identical with terrorism alleged or similar activities. In contrast, many students graduated from Pesantren Al Mukmin Ngruki that has excellent achievement.

In the pesantren there are also rules about language disciplindiscipline. This can form build students' the character of the language for students to be accustomed to in using a foreign language or Indonesian language when interacting with others students and teachers in the environment of boarding schools. In the interaction of everyday life, as adolescents as and expressive learners and always highlight the identity so that the process can form the personality of adolescents in language behavior. In the phase of looking for their identity, teenagers must be able to learn from aspects of linguistic abilities such as writing, speaking, listening, reading to produce a particular language well, this is because they have the power of critical analysis, objective thinking, creativity, and high imagination for the sustainability of the language used in the daily life of the community.

The students of a pesantren usually come from various area of Indonesia. Many teenagers in Indonesia, including students looking They study to look for knowledge to out of town far from his family in order to realize his ideals someday, professionals in the field and proficient in the science of religion. Basically, pPesantren have the closeness to go ahead and develop to empower themselves useful for the nation and society of the surrounding environment. In a bilingual or multilingual society can bring up the existence of various languages or variations of language in society. The choice of code is needed by the santri community in social interaction. The choice of code is a condition of a person in a bilingual or multilingual society speaking two or more languages and must choose which one to use (Fasold, 1984; Coulmas, 1997). Rokhman (2013) says that there are three categories in the choice of code, namely (1) selecting one variation of the same variation (intra language variation); (2) code switching; (3) code mixing.

The problem of language in society in Pesantren AlMukmin Ngruki is an interesting object to be studied. In bilingual/multilingual societies in pesantren have many vocabularies which are mastered both consciously and unconsciously because at certain times they are required to memorize vocabulary in foreign languages (English and Arabic). This may result in contact between two or more languages that occurs due to the acculturation process in social interaction and communication in the teaching-learning process as well as outside the teaching-learning activities within Pesantren Al Mukmin Ngruki. In such events it can cause speakers to make a choice of codes in communication 
events in pesantren, based on the explanation, the phenomenon of language occurring in bilingual and multilingual societies is always interesting to study from a Sociolinguistic perspective.

\section{RESEARCH METHODS}

This research is a qualitative research with Sociolinguistic approach. According to Creswell (2009) a qualitative approach has a purpose for data collection, analysis, interpretation, and report writing is different from the traditional qualitative approach. In Investigating investigating the choice of code on the made by the speaker of female students' of Madrasah Takhasushiyah Pesantren Al-Mukmin Ngruki. The writer choses Pesantren Al-Mukmin Ngruki with some considerations, first the pesantren community of various ethnic from both Java and outside Java, both the use of language in and outside the classroom is still much influenced by their own mother tongues as a communication language when outside of teaching and learning. It will affect the use of the language used in the pesantren. Pesantren Al Mukmin Ngruki prioritizes the ability of foreign languages both English and Arabic, this is realized in formal and informal activities such as daily conversations in pesantren, speech activities. The data in this study is santri in the domain of friendshipof friendship. Methods of data collection include observation, recording, indepth interviews, and questionnaires. Technique of analysis in this study also uses a contextual approach, namely by using the concept of speech components Hymes (SPEAKING).

\section{RESULT}

In this section will be is explained about the form of language choice in the environment of Pesantren Al-Mukmin Ngruki as follows.

\section{A. Indonesian Language (BI)}

Indonesian language is a state language that has an important role in both formal and non formal forums. The Indonesian language code includes the most dominant code used by the santri community when interacting with female students' both in the pesantren environment and outside the pesantren. The use of Indonesian non-formal variety can be seen from the choice of words used by female students' in the domain of friendship. This happens when the situation is relaxed in the communication interaction. It can be showed the female students' speech in the domain of friendship using Indonesian nonformal as follows.

Data 1

Santri 1 : bagaimana rasanya pertama kali masuk ke pesantren? "how did you feel for the first enter the pesantren?"

Santri 2 : rasanya sedih sekali karena jauh keluarga...selain itu aturan di pesantren sangat ketat...

: "I feel very sad because far away family ... besides that the rule in pesantren very tight"

Santri 1 : sama ya...namun yang pasti rasa sedih itu gak bisa menggoyahkan niat dan keinginan untuk belajar...
: "same with me ... but that surely the sad feeling can not shake the intention and want to learn "

Santri 2 : ya.....benar itu, tapi mungkin bagi orang yang tidak betah disini akan keluar...

: "yes .... it's true, but maybe for people who do not feel right here will come out"

The above mentioned conversation occurs between Santri 1 and Santri 2 in the dormitory, there is a form of Indonesian with a variety of nonformal. Indonesian can be seen in speech sama ya...namun yang pasti rasa sedih itu gak bisa mengggoyahkan niat dan keinginan untuk belajar. There is a word "gak" that comes from 'tidak'. In addition to the views of the use of words, Indonesian variety of non-formal can also be seen from the form of sentences used in the speech is not in accordance with the rules of language.

\section{B. Javanese Language (BJ)}

The code of Javanese language is used to communicate among female students'. Javaese ngoko language is usually used by female santris' from Java and have close relationship. Usually Javanese language code is used in a relaxed situation. Below is the example the use Javanese language code in the pesantren context.

Data 2

Santri 1 : Pit ku dhekwingi rusak!

: Sepedaku kemarin rusak!

: "my bike was broken yesterday!"

Santri 2 : kenapa?

: mengapa?

:"Why?"

Santri 1 : rantene pedhot

: rantainya putus

: "the chain was broken"

Santri 2 : terus piye, wis disambungke durung?

: lalu bagaimana, sudah disambung belum?

: "it has been connected yet?"

Santri 1 : lagi tak perbaiki

: baru diperbaiki

: "newly refined"

\section{Foreign Language (BA)}

The codes of language used to interact among santri community in Pesantren Al-Mukmin Ngruki. In addition, Indonesian language and Java language is foreign language code. The dominant of foreign language code used in social interaction among the santri community in Pesantren AlMukmin Ngruki consists of English and Arabic codes. Arabic is one of the most dominant codes of foreign language used for intercultural verbal interaction both in teaching-learning activities and in daily interactions.

Data 3

Santri 1: Assalamu'alaikum

Santri 2: Wa'alaikumsallam

Santri 1 : saya mau ambil penaku

: I want to borrow my pen 
Santri 2 : ayna yaa qalamuki? Nasitu ayna? ha...hadza hadza!!! Shahih am la'?

: mana ya penamu? Aku lupa dimana.. Ha...ini..ini! betul ga?

: where is your pen? I forgot. Ha ... this..this! right?

Santri 1 : shahih...shahih...hadza qalamii. Sukron ya...

: betul...betul..ini penaku. Terima kasih ya...

: right ... that's right ... this is my pen. Thank you

In addition, Arabic code, the female students' also uses English code. English is an international language that must be mastered by santri. English code can occur in both formal and nonformal situations. Here is an example of female students' using the following English code.

Data 4

Santri 1 : Good morning, what is your activity on Sunday?

Santri 2 : I usually help my mother cook fried rice?

Santri 1 : owh...it's interesting..

Santri 2 : Yes..I like cooking

Santri 1 : kapan-kapan bisa masak bersama ya...

: Could you cook together?

Santri 2 : Okey...

\section{Other Local Languages $(B D L)$}

Other local langauges used to communicate among female santris'. There are some other local language codes used to interat at Pesantren AL Mukmin Ngruki. Other local language codes (BDL) are very dominant namely Banjar language code and Malay language code. Usually Banjar language is used by female student from Kalimantan. It is very limited while the Malay language is used by female student from the island of Sumatra. In addition, some santri from North Kalimantan also use Malay language. Below the example of the conversation between female student as follows.

Data 5

Santri 1 : Nak kemane?

: mau kemana?

:"where do you go?

Santri 2 : ke kantin, nak beli permen.

: ke kantin, mau beli permen

: " to the canteen, I want to buy candy."

Santri 1 : Nak ikut bulih tak?

: mau ikut boleh gak?

: "May I go with you?

Santri 2 : bulih...tapi nak bagi

: boleh, tapi gak mau bagi

: Yes, but I don't give it to you."

Santri 1 : ay...kedeyutnye

: pelit banget

: it's so stingy

Santri 2 : hihi...temberang je

: hihi..becanda aja

: hey...it's a joke

Data 6
Santri 1 : Ikam hendak kemana?

: Kamu mau kemana?

: where do you go?

Santri 2 : hendak mbasuh tangan

: Hendak cuci tangan

: wash my hand

Santri 1 : dimana pang?

: Dimana?

: where?

Santri 2 : reservoir. Ikut kada?

: Reservoir. Ikut nggak

: Reservoir. Do you want to join us?

Santri 1 : hi'ih

: iya

: Okey

Santri 2 : ayo, lakas

: ayo, cepat

: come on..hurry up

\section{CONCLUSION}

Based on the results of mentioned above, it can be concluded that the choice of codes used by female students' who come from various ethnic and multilingual in Pesantren Al-Mukmin Ngruki is a code in the form of Indonesian language (BI), Javanese (BJ), other local language (BDL), and Foreign Languages (BA). The most dominant language used is Indonesian language, especially non standart Indonesian. Javanese language is used in social interactions that are already familiar. Arabic is a compulsory language used by female students' to interact in the environment of Pesantren Al-Mukmin Ngruki. Furthermore, English is also used by female students' although mixed with the code in Indonesian. In addition to Indonesian (BI), Javanese (BJ), Foreign languages (Arabic and English) there are also other local languages (BDL), Malay and Banjar.

\section{References}

Coulmas, F. (1997). The handbook of Sociolinguistics. USA: Blackwell Publishing.

Fasold. (1984). The Sociolinguistics of society. Oxford: Basil Blackwell Publisher Ltd.

Holmes (2001). An introduction to Sociolinguistic. Second edition. Essex: Pearson Education Limited. (1992). An Introduction to Sociolinguistics. London: Longman.

Hymes, D. (1974). Foundations in Sociolinguistics: An Ethnographic approach. Philadelphia: University of Pennsylvania Press.

Hudson, R. R. A. (1996). Sociolinguistics. Second edition. Cambrigde: Cambridge University Press.

Rokhman, F. (2013). Sosiolinguistik: Suatu pendekatan pembelajaran bahasa dalam masyarakat multikultural. Yogyakarta: Graha Ilmu 
Santosa, R. (2017). Metode penelitian kualitatif kebahasaan. Surakarta: Universitas Sebelas Maret Press.
Wardhaugh, R. (1998). An intoduction to Sociolinguistics. Third Edition. Oxford: Basil Blackwell Ltd 